\title{
Implementation of resuspension from paved roads for the improvement of CALIOPE air quality system in Spain
}

\author{
María T. Pay ${ }^{\mathrm{a}}$, Pedro Jiménez-Guerrero ${ }^{\mathrm{c}}$, José M. Baldasano ${ }^{\mathrm{a}, \mathrm{b}}$ \\ ${ }^{a}$ Earth Sciences Department, Barcelona Supercomputing Center-Centro Nacional de \\ Supercomputacion, Barcelona, Spain. \\ ${ }^{\mathrm{b}}$ Environmental Modeling Lab, Technical University of Catalonia, Barcelona, Spain. \\ ${ }^{\mathrm{C}}$ Physics of the Earth, University of Murcia, Spain.
}

\section{Abstract}

Emissions of resuspensed particles from paved roads (RPR) have received an increasing attention in air quality modeling, since chemistry transport models are generally unable to reproduce particulate levels near road traffic. However, among the models operated in the forecasting mode in Europe, there is a lack of systems including the contribution of RPR on an hourly basis. Therefore, this contribution describes the inclusion of the resuspension of particulate matter within HERMES emission model (operationally implemented in the CALIOPE forecasting system) and the improvements obtained in the simulations of the PM10 mass over a domain covering Spain for a whole year of simulation (2004). The results indicate a remarkable improvement of the PM10 predictions, reducing the biases and errors around $15-18 \%$ and $2.6 \mu \mathrm{g} \mathrm{m}^{-3}$ for the average bias in all Spain. The RPR emission have strong local effects on the modeled particle concentration in or near the largest urban zones (up to $7 \mu \mathrm{g} \mathrm{m}^{-3}$ as the annual average), albeit those positive effects are more limited in background areas, since the deposition mechanism was found to be a significant sink for RPR in the chemistry transport model. This approach is accurate and effective in order to improve the prediction of the PM10 mass and becomes essential to achieve the standards set in the regulations for modelling applications.

Corresponding author at: Earth Science Department, Barcelona Supercomputing CenterCentro Nacional de Supercomputación (BSC-CNS), Jordi Girona 29, Edificio Nexus II, 08034 Barcelona, Spain. Tel.: +34 9341377 19; Fax: +34 934137721.

Email address: jose.baldasano@bsc.es (J.M. Baldasano)

Keywords: air quality, forecasting, emissions, urban air quality

\section{Introduction}

Field measurements in urban areas or megacities showed elevated levels of PM10 in the vicinity of roads coming from the contribution from resuspended particles from paved roads (Lenschow et al., 2001; Querol et al., 2004; Ketzel et al., 2007; Querol et al., 2008).

42 However, it is widely known that chemistry transport models are generally unable to 
reproduce particulate levels near road traffic. For instance, Vautard et al. (2005) and Pay et al. (2010) showed that simulated aerosol loadings, using the current knowledge on aerosol mechanisms, show a pervasive trend towards an underestimation by up to $30-50 \%$.

Hence, since a decade, emissions of resuspensed particles from paved roads (later referred to as RPR) have received an increasing attention in air quality modelling and forecasting. The first model attempts to quantify particle emissions resulting from abrasion of vehicle components and road surface were presented by Rauterberg-Wulff (2000); LUA (2000); Venkatram (2000) following a preliminary formulation by US-EPA (1997), later improved by US-EPA (2006). Empirical emission factors are presently retrieved from various field campaigns at different locations and road types (During et al., 2002, 2004; Mellios et al., 2006; Markakis, 2008). More recently, the resuspendable amount of particles was experimentally evaluated in Barcelona (Spain) by Amato et al. (2009a,b, 2010), demostrating that the contribution from road dust resuspension in the coarse fraction is comparable or even higher than the exhaust emissions in this urban environment. In this sense, Spain represents a paradigmatic case of study, since regions with low precipitation climates favour the accumulation of paved road dust and the resuspension of loose material on the road surface (Abu-Allaban et al., 2003; Thorpe and Harrison, 2008).

Nowadays, a total of 23 model systems routinely simulate the air quality over Europe, with seven systems also operated in the forecasting mode (Menut and Bessagnet, 2010). Because of the complexity of the physical processes leading to resuspension and the difficulties in measuring and/or modelling their effects on ambient PM levels, CALIOPE (Baldasano et al., 2008a) is the unique system including the contribution of resuspension of particulate matter on an hourly basis, to the authors' knowledge. Emission inventories of non-exhaust emissions are scarce despite their suitability for researchers and regulating agencies for managing air quality and PM reduction measures (Oxley et al., 2009). Therefore, this contribution intends to describe the inclusion of RPR within HERMES (the emission model in CALIOPE) and the improvements obtained in the simulations of the PM10 mass over a domain covering Spain for a whole year of simulation (2004).

\section{Methods}

\subsection{The CALIOPE modeling and forecasting system}

The CALIOPE project, funded by the Spanish Ministry of the Environment and Rural and Marine Affairs, aims at establishing an air quality forecasting system for Spain (Baldasano et al., 2008a). CALIOPE encompasses a high-resolution air quality forecasting system being applied to Europe as a mother domain $(12 \mathrm{~km} \mathrm{x} 12 \mathrm{~km}, 1 \mathrm{hr}$ ) (Pay et al., 2010) as well as to Spain as the nested domain ( $4 \mathrm{~km} \mathrm{x} 4 \mathrm{~km}, 1 \mathrm{hr}$ ) (Baldasano et al., 2010). Such high resolution of the model system is made possible by its implementation on the MareNostrum supercomputer hosted by the Barcelona Supercomputing Center-Centro Nacional de Supercomputacion (BSC-CNS). CALIOPE is a complex ensemble of models that integrates a meteorological model (WRF-ARWv3.0.1.1), an emission processing model (HERMES), a mineral dust dynamic model (BSC-DREAM8b), and a chemical 
transport model (CMAQv4.5) together in an air quality modeling and forecasting system. Current forecasts are available through http://www.bsc.es/caliope.

The HERMES model uses information and state-of-the-art methodologies for emission estimations. It calculates emissions by sector-specific sources or by individual installations and stacks following a bottom-up approach. Raw emission data are processed by HERMES in order to provide a comprehensive description of the emissions to the air quality model. Emissions used for the Iberian Peninsula are derived from the aggregation in space from 1 $\mathrm{km} \times 1 \mathrm{~km}$ dataset to $4 \mathrm{~km} \times 4 \mathrm{~km}$. A more detailed description can be found in Baldasano et al. (2008b).

Specifically, the on-road traffic emissions module takes into account 72 diesel and gasoline vehicles categories according to COPERT III-CORINAIR methodology (Ntziachristos and Samaras, 2000; EEA, 2006); divided by fuel type, vehicle weight, age of the vehicle and cubic capacity; each of them with its specific emissions factors, defined as a function of the circulation speed. The model includes the definition of the road network, dividing it in stretches with specific temporary disaggregating profiles (distinguishing day-type: weekday-holiday, and month), specific average speed, daily average traffic (number of vehicles per day), stretch length, route type (highway, road or urban) and circulation zones. The emissions account in the on-road traffic module considers hot exhaust, cold exhaust and evaporative emissions. It also estimates particulate matter produced by brakes abrasion, tire wear and pavement erosion. The methodology described below presents a new approach to the inclusion of non-exhaust particulate matter originated by the resuspension from paved roads within the on-road traffic emission module of HERMES. The calculation of the emissions of RPR is proportional to the daily average traffic (DAT) measured in 20934 observation points throughout Spain. Hourly emissions are based on coefficients calculated with the hourly distribution of the DAT (Baldasano et al., 2008b). The RPR emissions in the road section $\mathrm{r}$ of k-cell per hour are calculated with Eq. 1:

$E_{r}^{\text {ires }}(k$, hourly $)=C r h \cdot \sum_{j=1}^{n} C l f \cdot C r d \cdot D A T_{r j}(k) \cdot L_{r}(k) \cdot F^{\text {ires }}(1)$

where Crh is the proportion of DAT at h-hour; Clf, the coefficient for daily traffic (labour day or weekend); Crd is the ratio between daily traffic for a specific month and DAT; $\mathrm{DAT}_{\mathrm{rj}}(\mathrm{k})$ is the daily average traffic for r-road section and $\mathrm{j}$-vehicle category in k-cell (number of vehicles); $\mathrm{L}_{\mathrm{r}}(\mathrm{k})$ represents the length of the road section $\mathrm{r}$ in $\mathrm{k}$-cell $(\mathrm{km}) ; \mathrm{n}$ is the number of vehicle categories considered in HERMES emission model (72 in the present version); and $\mathrm{F}^{\mathrm{ires}}$ is the road dust emission factor. As a first approach, the measured PM10 emission factor presented in During et al. (2002) has been included (0.088 grams per vehicle kilometer travelled $\left(\mathrm{g} \mathrm{vkt}^{-1}\right)$ for cars and $0.217 \mathrm{~g} \mathrm{vkt}^{-1}$ for trucks).

Under precipitation conditions, emissions decrease proportionally to the frequency of measurable precipitation. The precipitation effect is included by the application of a correction factor $\left(f_{\text {prep }}\right)$ on an hourly basis following the equation proposed by US-EPA (2006). This factor is calculated with Eq. 2: 
$f_{\text {prep }}=\left(1-1.2 \times \frac{P}{N}\right)(2)$

where $\mathrm{P}$ is the number of hours with at least $0.254 \mathrm{~mm}$ of precipitation during the averaging period, and $\mathrm{N}$ is the number of hours in the averaging period. For a precipitation situation occurring continuously for over 48 hours, the emissions of RPR are switched off in HERMES. The accumulated precipitation is hourly provided by the WRF-ARW model.

Despite the diameter of RPR spans several orders of magnitude, the peak in the mass distribution is usually in the coarse size range (aerodynamic diameter greater than $2.5 \mu \mathrm{m}$ ) and therefore the emissions of resuspended particles are speciated into this fraction in the HERMES emission model. In the CMAQ chemistry transport model, coarse particles are described with a unimodal lognormal distribution (Byun and Schere, 2006). The coarse particle mode is treated as dry and chemically inert with a fixed geometric standard deviation of 2.2 (Kelly et al., 2010).

For the present contribution two air quality simulations were performed over a domain covering Spain for a whole year of simulation (2004): (1) taking into account the RPR module within HERMES and (2) without the aforementioned module, here in after referred to as CALIOPE-IP-RPR and CALIOPE-IP, respectively.

\section{Results}

In order to evaluate the implementation of resuspended particles within HERMES emission model, the discussion will focus on a whole year of simulations (year 2004) over the Iberian Peninsula. Figure 1, left displays the 112 impact of the inclusion of RPR for PM10 emissions in Spain. This contribution is calculated by averaging the emitted loadings from the RPR module for each grid cell on the 24 hours and is expressed in $\mathrm{kg} \mathrm{h}^{-1} \mathrm{~km}^{-2}$. The impact of this module is highest in cities of dense population such as Madrid, Barcelona or Valencia, with maximum average values increasing up to $10-18 \mathrm{~kg} \mathrm{~h}^{-1} \mathrm{~km}^{-2}$ downtown the largest conurbations, doubling the emissions when no resuspension is included in HERMES. The radial highways with the largest daily average traffic undergo a mean increase of $1 \mathrm{~kg} \mathrm{~h}^{-1}$ while the rest of the territory is mostly not affected by the RPR module.

Figure 1, center represents the average contribution of the RPR module in terms of PM10 air concentrations at the surface layer for the same period. Both emission and air concentration patterns display similar behaviors. The RPR module mainly affects PM10 concentrations in Madrid with an average annual increase of around 4 to $10 \mu \mathrm{g} \mathrm{m}^{-3}$ depending on the area of the city observed (with hourly maxima of $26 \mu \mathrm{g} \mathrm{m}^{-3}$ at rush hours, Fig 2, up). This increase is similar in the city of Barcelona, with average increases ranging from 3 to $7 \mu \mathrm{g} \mathrm{m}^{-3}$ as the annual average. In other major Spanish cities particulate levels rather increase by 2 to $5 \mu \mathrm{g} \mathrm{m}^{-3}$. PM10 concentrations in more remote areas are not substantially impacted upon by the inclusion of the resuspension module. Figure 1, center shows that such a module may have strong local effects on the modeled particle concentrations in or in the vicinity of the largest urban zones, but not in the downwind areas from the local emitting sources. 
In the domain of Spain, RPR emissions were included in the coarse fraction of the HERMES emission model. The deposition mechanism was found to be an important sink for resuspended particles from paved roads (Figure 1, right. Dry and wet depositions largely contribute to the air cleansing. Dry and wet depositions amounted 6-15 $\mathrm{kg} \mathrm{h}^{-1} \mathrm{~km}^{-2}$ depending of the urban area, that is, from $60 \%$ to $90 \%$ of the total coarse particles emitted in large cities and on the main roads. The high local contribution and the lack of transport of coarse particulate matter is associated to the short lifetime of this kind of particles in the atmosphere as a consequence of the deposition implemented in CMAQ chemistry transport model. In this sense, Zhang et al. (2006) and Jiang et al. (2006) report an over-prediction of geometric mean diameter by CMAQ and Elleman and Covert (2009) also reported that CMAQ aerosol size distributions are shifted to a larger size compared with observations. Therefore, the deposition of coarse-mode particles is too rapid in CMAQ (Kelly et al., 2010). This fact may importantly PM10 predictions, that will increase if over-predictions of the geometric mean diameter were corrected, because a large fraction of the coarse mode would fail to the accumulation mode and hence deposition velocities would become much smaller.

Figure 2 represents the time series of observed and modeled concentrations of PM10 at the urban traffic station of Madrid-Recoletos (as a paradigmatic study case since at this station as the measuring instrument is mainly affected by road activities from the intense traffic nearby) and the average behaviour of all the urban traffic stations considered in the domain of study for which the PM10 increases are over $1 \mu \mathrm{g} \mathrm{m}^{-3}$. All of these stations are located in the large metropolitan areas of Madrid (Recoletos and Alcobendas), Castellón (Castellón) and Malaga (Ps. Martiricos) with over 500,000 inhabitants where urban streets are specifically described in the HERMES model. Madrid-Recoletos is located in a wide avenue in central Madrid. The RPR module induces a mean annual increase of $2.8 \mu \mathrm{g} \mathrm{m}^{-3}$ in PM10 air concentrations in the coarse fraction compared to the annual simulation including no RPR module, which can achieve $4.2 \mu \mathrm{g} \mathrm{m}^{-3}$ in several stations and areas (Figure 1).

Table 1 summarizes the performance of the modeling system in the scenarios with or without resuspension, evaluated by means of comparisons with ground-based observations, located throughout the Iberian Peninsula. The dynamics are better reproduced when the RPR module is implemented, and the mean bias is reduced from $-21.5 \mu \mathrm{g} \mathrm{m}^{-3}$ to $-18.8 \mu \mathrm{g}$ $\mathrm{m}^{-3}$. The root mean squared error also decreases when RPR is included, with improvements in the predictions ranging from $0.3 \mu \mathrm{g} \mathrm{m}^{-3}$ in Málaga-Ps. Martiricos to $3.0 \mu \mathrm{g} \mathrm{m}^{-3}$ in Madrid-Recoletos. The global improvement of the bias and root mean squared error is 2.6 $\mu \mathrm{g} \mathrm{m}^{-3}$ and $1.9 \mu \mathrm{g} \mathrm{m}^{-3}$. Overall, the hourly temporal variability improves with the inclusion of the RPR module; the correlation coefficients increase from 0.41 to 0.48 globally. The mean fraction scores are higher for all the stations when RPR emissions are included; the mean fractional bias and error improves by $18.3 \%$ and $15.5 \%$, respectively. Hence, the inclusion of RPR importantly contributes to the achievement in several stations of the criteria established by Boylan and Russell (2006) for model performance regarding particulate matter (mean fractional error $\leq 75 \%$ and mean fractional bias $\leq \pm 60 \%$ ).

At some events mainly are associated to winter meteorological conditions favoring the accumulation of pollutants (dry day, weak dispersion)(see January and mid-March in 2), 
PM10 concentrations are increased by up to $30 \mu \mathrm{g} \mathrm{m}^{-3}$. These events are associated with meteorological conditions favoring the accumulation of pollutants (dry day, weak

\section{Conclusions}

In this study, an emission module including resuspended particles from paved roads has been implemented in the CALIOPE air quality modeling and forecasting system (http://www.bsc.es/caliope) and assessed against observations for period covering the whole year 2004. The impact of the newly developed emission module considering RPR inclusion in the CALIOPE air quality modeling system highly improves the PM10 predictions in those areas of dense population in Spain, around 15-18\% for the mean fractional scores and $2.6 \mu \mathrm{g} \mathrm{m}^{-3}$ for the average bias in all Spain. The RPR emission may have strong local effects on the modeled particle concentration in or near the largest urban zones (up to $7 \mu \mathrm{g} \mathrm{m}^{-3}$ as the annual average and a contribution of $30 \mu \mathrm{g} \mathrm{m}^{-3}$ to the rush hour peaks). Those positive effects are, however, more limited in background areas, since the deposition mechanism was found to be a significant sink for resuspended particulate matter from paved roads in the chemistry transport model.

However, there are still some development tasks for a better reproduction of particulate matter in the CALIOPE system. Presently, further research is devoted to the inclusion of specific emission factors for the area of Spain (from Amato et al. (2010), instead of those of During et al. (2002) which represent the conditions of more northern latitudes). Moreover, the large uncertainties in local natural erosion emissions resulting from saltation processes need further development in emission estimates and modelling, especially for the conditions in the Iberian Peninsula. Despite the aforementioned limitations, the results demonstrate that this first approach is accurate and effective in order to improve the prediction of the PM10 mass and becomes essential to achieve the standards set in the regulations for modelling applications.

\section{Acknowledgments}

The authors wish to thank the CEAM, CIEMAT and CSIC-IJA centers for their collaboration in the project. Also, thanks to S. Basart and C. Pérez for providing the BSCDREAM8b outputs and L. González for their work related to the CALIOPE system. This work is funded by the CALIOPE project of the Spanish Ministry of the Environment (441/2006/3-12.1, A357/2007/2-12.1, 157/PC08/3-12.0). The Spanish Ministry of Science and Innovation is also thanked for the Formación de Personal Investigador (FPI) doctoral fellowship held by María Teresa Pay (CGL2006-08903). All simulations were performed on the MareNostrum supercomputer hosted by the Barcelona Supercomputing Center. 
Abu-Allaban, M., Gillies, J.A., Gertler, A.W., Clayton, R., Pro_tt, D., 2003. Tailpipe, resuspended road dust, and brake-wear emission factors from on-road vehicles. Atmos. Environ. 37, 5283-5293.

Amato, F., Pandolfi, M., Escrig, A., Querol, X., Alastuey, A., Pey, J., Pérez, N., Hopke, P.K., 2009a. Quantifying road dust resuspension in urban environment by multilinear engine: A comparison with pmf2. Atmos. Environ. 43, 2770-2780.

Amato, F., Pandolfi, M., Viana, M., Querol, X., Alastuey, A., Moreno, T., 2009b. Spatial and chemical patterns of PM10 in road dust deposited in urban environment. Atmos. Environ. 43, 1650-1659.

Amato, F., Nava, S., Lucarelli, F., Querol, X., Alastuey, A., Baldasano, J.M., Pandolfi, M., 2010. A comprehensive assessment of PM emissions from paved roads: Real-world emission factors and intense street cleaning trials. Sci. Total Environ., doi: 10.1016/j.scitotenv.2010.06.008.

Baldasano, J.M., Jiménez-Guerrero, P., Jorba, O., Pérez, C., López, E., Güereca, P., Martín, F., Vivanco, M.G., Palomino, I., Querol, X., Pandolfi, M., Sanz, M.J., Diéguez, J.J., $2008 b$. Caliope: an operational air quality forecasting system for the Iberian Peninsula, Balearic Islands and Canary Islands - First annual evaluation and ongoing developments. Adv. Sci. Res. 2, 89-98.

Baldasano, J.M., Güereca, L.P., López, E., Gassó, S., 245 Jiménez-Guerrero, P., 2008 a. Development of a high-resolution $(1 \mathrm{~km} \times 1 \mathrm{~km}, 1 \mathrm{~h})$ emission model for Spain: The HighElective Resolution Modelling Emission System (HERMES). Atmos. Environ. 42, 72157233.

Baldasano, J.M., Pay, M.T., Jorba, O., Jiménez-Guerrero, P., 2010. An annual assessment of air quality with the CALIOPE modeling system over Spain. Submitted for publication.

Boylan, J., Russell, A., 2006. PM and light extinction model performance: Metrics, goals and criteria for three-dimensional air quality models. Atmos. Environ. 40, 4946-4959.

Byun, D., Schere, K.L., 2006. Review of the governing equations, computational algorithms, and other components of the Models-3 Community Multi scale Air Quality (CMAQ) modeling system. Appl. Mech. Rev. 59 (2), 5177.

Düring, I., Jacob, J., Lohmeyer, A., Lutz, M., Reichenbacher, W., 2002. Estimation of the "non-exhaust pipe" PM10 emissions of streets for practical traffic air pollution modelling, in: 11th Intl. Symposium on Transport and Air Pollution, Graz University of Technology, Institute for Internal Combustión Engines and Thermodynamics, vol 1., pp. 309-316. 
Düring, I., Wolfgang, B., Bsinger, R., Wolfgang, J., Lohmeyer, A., 2004. Experiences when modelling roadside PM10 concentration, in: JRC-EI (Ed.), Proceedings of the 9th International conference on Harmonisations within Atmospheric Dispersion Modelling for Regulatory Purposes, Garmisch Partenkirchen. pp. 208-212.

EEA, 2006. EMEP-CORINAIR Emission Inventory Guidebook 2006. European Environmental Agency Technical Report N.30. http://reports.eea.europa.eu/EMEPCORINAIR4/en/page002.html

Elleman, R.A., Covert, D. S., 2009. Aerosol size distribution modeling with the Community Multiscale Air Quality modeling system (CMAQ) in the Pacific Northwest: 1. Model comparison to observations. J. Geophys. Res. 114, D11206, doi:10.1029/2008JD010791.

Jiang, W., Smith, S., Giroux, E, Roth, H., Yin, D., 2006. Differences between CMAQ fine mode particle and PM2.5 concentrations and their impact on model performance evaluation in the lower Fraser valley. Atmos. Environ. 40(26), 4973-4985.

Kelly, J.T., Bhave, P.V., Nolte, C.G., Shankar, U., Foley, K.M., 2010. Simulating emission and chemical evolution of coarse sea-salt particles in the Community Multiscale Air Quality (CMAQ) model. Geosci. Model Dev. 3, 257-273.

Ketzel, M., Omstedt, G., Johansson, C., Düring, I., Pohjola, M., Oettl, D., Gidhagen, L., Wåhlin, P., Lohmeyer, A., Haakana, M., Berkowicz, R., 2007. Estimation and validation of PM2.5/PM10 exhaust and non-exhaust emission factors for practical street pollution modeling. Atmos Environ 41, 9370-9385.

Lenschow, P., Abraham, H.J., Kutzner, K., Lutz, M., Preu, J.D., Reichenbcher, W., 2001. Some ideas about the sources of PM10. Atmos. Environ. 285 35, Supplement No. 1, S23.

LUA, 2000. Vorgehensweise bei der Schwebstaubimmissionsberechnung nach Richtlinie 1999/30/EG. Technical Report. Landesumweltamt Brandenburg, Entwurf des Referats I3 vom 21.12.2000.

Markakis, K., 2008. Quanti_cation and evaluation of dust resuspension PM10 emissions in two large urban centers in Greece, in: JRC-EI (Ed.), Proceedings of the 12th International conference on Harmonisations within Atmospheric Dispersion Modelling for Regulatory Purposes, Cavtat. pp. 543-547.

Mellios, G., Aalst, R.V., Samaras, Z., 2006. Validation of road traffic urban emission inventories by means of concentration data measured at air quality monitoring stations in Europe. Atmos. Environ. 40, 7362-7377.

Menut, L., Bessagnet, B., 2010. Atmospheric composition forecasting in Europe. Annals Geoph. 28, 61-74. 
Ntziachristos, L., Samaras Z., 2000. COPERT III. Computer programme to calculate emissions from road transport. Methodology and emission factors (Version 2.1). European Environmental Agency Technical Report N.49, 86-301.

Oxley, T, Valiantis, M., Elshkaki, A., ApSimon, H.M., 2009. Background, Road and Urban Transport modelling of Air quality Limit values (The BRUTAL model). Environmental Modelling \& Software 24, 1036-1050, doi:10.1016/j.envsoft.2009.02.011.

Pay, M.T., Piot, M., Jorba, O., Basart, S., Gass, S., Jimnez-Guerrero, P., Gonalves, M., Dabdub, D., Baldasano, J.M., 2010. A full year evaluation of the CALIOPE-EU air quality system in Europe for 2004: a model study. Atmos. Environ. 44, 3322-3342, doi:10.1016/j.atmosenv.2010.050140.

Querol, X., Alastuey, A., Ruiz, C.R., Artiano, B., Hansson, H.C., Harrison, R.M., Buringh, E., ten Brink, H.M., Lutz, M., Bruckmann, P., Straehl, P., Schneider, J., 2004. Speciation and origin of PM10 and PM2.5 in selected European cities. Atmos. Environ. 38, 65476555 .

Querol, X., et al., 2008. Spatial and temporal variations in airborne particulate matter (PM10 and PM2.5) across Spain 19992005. Atmos. Environ. 42, 3964-3979.

Rauterberg-Wulff, 2000. Untersuchung ber 313 die Bedeutung der Staubaufwirbelung fr die PM10-Immission an einer Hauptverkehrsstrae. Technical Report. Techn. Univ. Berlin, Fachgebiet Luftreinhaltung.

Thorpe, A., Harrison, R.M., 2008. Sources and properties of non-exhaust particulate matter from road traffic: a review. Sci. Total Environ. 400, 279-282.

US-EPA, 1997. AP-42, 5. Edition, Volume 1, Chapter 13, Section 13.2.1. Miscellaneous sources. Technical Report. U.S. Environmental Protection Agency.

US-EPA, 2006. AP-42. 5th Edition, Volume VI, Chapter 13, Section 13.2.1. Paved Roads. Technical Report. U.S.-Environmental Protection Agency. US-EPA, 2007. Guidance on the Use of Models and Other Analyses for Demonstrating Attaintment of Air Quality Goals for Ozone, PM2.5, and Regional Haze. Technical Report. EPA-454/B-07-002. U.S. Environmental Protection Agency, Office of Air Quality Planning and Standards: Research Triangle 327 Park, NC.

Vautard, R., Bessagnet, B., Chin, M., Menut, L., 2005. On the contribution of natural aeolian sources to particulate matter concentrations in Europe: Testing hypotheses with a modelling approach. Atmos. Environ. 39 (18), 3291-3303, doi:10.1016/j.atmosenv.2005.01.051.

Venkatram, A., 2000. A critique of empirical emission factor models: a case study of the AP-42 model for estimating PM10 emissions from paved roads. Atmos. Environ. 34, 1-11. 

of MM5-CMAQ for the summer 1999 southern oxidants study episode Part III: diagnostic and mechanistic evaluations. Atmos. Environ. 40, 4856-4873.

Table 1: PM10 annual statistics obtained with the CALIOPE system with and without the inclusion of RPR emissions at several urban traffic stations and global average from the air quality Spanish monitoring network. Statistics parameters are: number of data $(\mathrm{N})$, observed mean $(\mathrm{OM})$, modeled mean $(\mathrm{MM})$, correlation coeffcient $(\mathrm{r})$, root mean quare error (RMSE), mean bias (MB), mean fractional bias (MFB) and mean fractional error (MFE).

\begin{tabular}{|c|c|c|c|c|c|c|c|c|c|c|c|c|c|c|}
\hline \multirow[b]{2}{*}{$\begin{array}{c}\text { Station } \\
\text { name }\end{array}$} & \multirow[b]{2}{*}{$\mathrm{N}$} & \multirow[b]{2}{*}{$\begin{array}{c}\mathrm{OM}^{-} \\
\left(\mu \mathrm{g} \mathrm{m}^{-}\right. \\
\left.{ }^{3}\right)\end{array}$} & \multicolumn{6}{|c|}{ CALIOPE-IP } & \multicolumn{6}{|c|}{ CALIOPE-IP-RPR } \\
\hline & & & $\begin{array}{c}\mathrm{MM} \\
\left(\begin{array}{c}\mu \mathrm{g} \mathrm{m}^{3} \\
-\end{array}\right.\end{array}$ & $\mathrm{r}$ & $\begin{array}{l}\text { RMSE } \\
\left(\mu \mathrm{g} \mathrm{m}^{-}\right. \\
3)\end{array}$ & $\begin{array}{c}\mathrm{MB} \\
\left(\begin{array}{c}\mu_{3} \mathrm{~g} \mathrm{~m}^{-} \\
-\end{array}\right.\end{array}$ & $\begin{array}{c}\text { MFB } \\
(\%)\end{array}$ & $\begin{array}{c}\text { MFE } \\
(\%)\end{array}$ & $\begin{array}{c}\mathrm{MM} \\
\left(\begin{array}{c}\mu \mathrm{g} \mathrm{m}^{3} \\
-\end{array}\right.\end{array}$ & $\mathrm{r}$ & $\begin{array}{l}\text { RMSE } \\
\left(\mu \mathrm{g} \mathrm{m}_{3}^{-}\right. \\
\left.{ }^{-}\right)\end{array}$ & $\begin{array}{c}\mathrm{MB} \\
\left(\mu \mathrm{g} \mathrm{m}_{3}^{-}\right.\end{array}$ & $\begin{array}{c}\text { MFB } \\
(\%)\end{array}$ & $\begin{array}{c}\text { MFE } \\
(\%)\end{array}$ \\
\hline $\begin{array}{c}\text { Madrid- } \\
\text { Recoletos }\end{array}$ & 8740 & 36.3 & 10.2 & 0.49 & 38.1 & -26.2 & -104 & 109 & 14.4 & 0.50 & 35.1 & -22.3 & -80 & 90 \\
\hline $\begin{array}{l}\text { Málaga-Ps. } \\
\text { Martiricos }\end{array}$ & 8416 & 16.2 & 12.2 & 0.42 & 13.0 & -3.9 & -46 & 70 & 13.3 & 0.43 & 12.7 & -2.8 & -34 & 62 \\
\hline $\begin{array}{l}\text { Castellón- } \\
\text { Castellón }\end{array}$ & 4420 & 36.3 & 10.9 & 0.46 & 34.3 & -26.8 & -113 & 115 & 15.1 & 0.46 & 31.4 & -23.0 & -91 & 95 \\
\hline $\begin{array}{l}\text { Madrid- } \\
\text { Alcobendas }\end{array}$ & 8598 & 36.0 & 7.1 & 0.55 & 40.6 & -28.9 & -133 & 135 & 8.8 & 0.55 & 39.1 & -27.2 & -118 & 120 \\
\hline Global & 30171 & 30.6 & 9.3 & 0.38 & 33.7 & -21.6 & -101 & 108 & 12.8 & 0.41 & 31.4 & -18.4 & -80 & 92 \\
\hline
\end{tabular}

416

417

418

419

420

421

422

423

424

425

426

427

428

429

430

431

432

433

434

435

436 
Figure 1: (Left) Emissions of coarse aerosol including RPR (up) and contribution of RPR to total emissions of the coarse fraction (bottom); (Center) Air quality contribution of the coarse fraction to PM10 levels including RPR (up) and contribution of RPR to PM10 440 concentrations (bottom); (Right) Total deposition of coarse aerosols including RPR (up) 441 and difference in the total deposition of coarse particulate matter with the simulation not 442 including RPR (down).
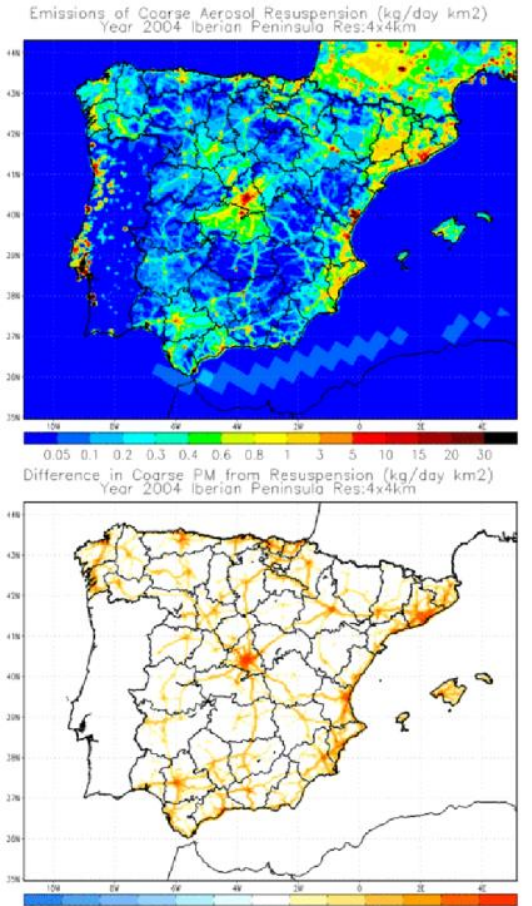

445

446

447

448

449

450

451

452

453

454

455

456

457

458

459

460

461

462

463

464
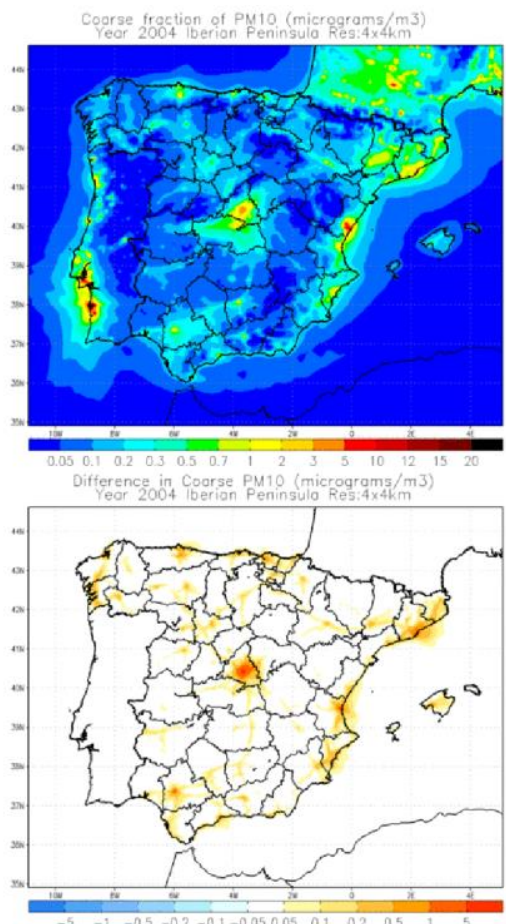

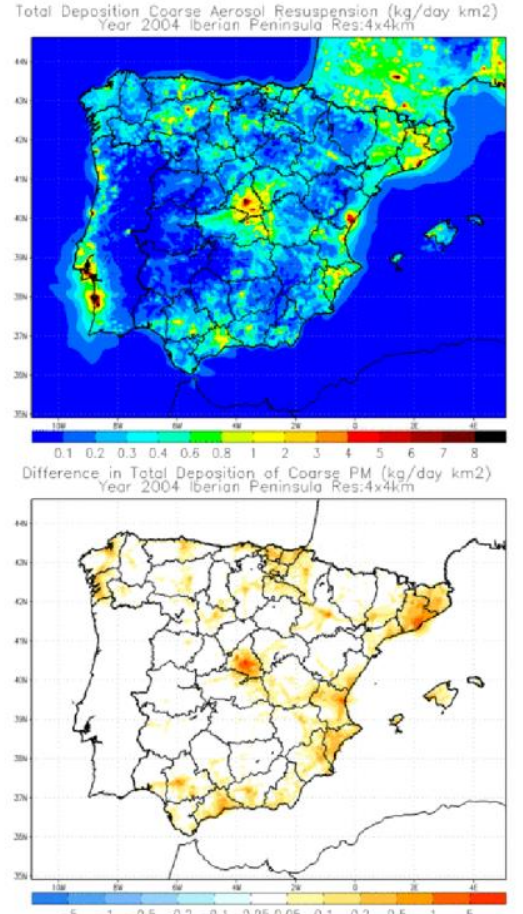


465 Figure 2: Annual hourly series of PM10 in the station of Madrid-Recoletos (up) and the 466 average of urban traffic stations in Spain (bottom) over 2004: observations from the 467 Spanish monitoring network, namely RedESP (black dots); model including RPR, namely 468 CALIOPE-IP (red); and without the inclusion of the RPR module, namely CALIOPE-IP 469 (blue).

470
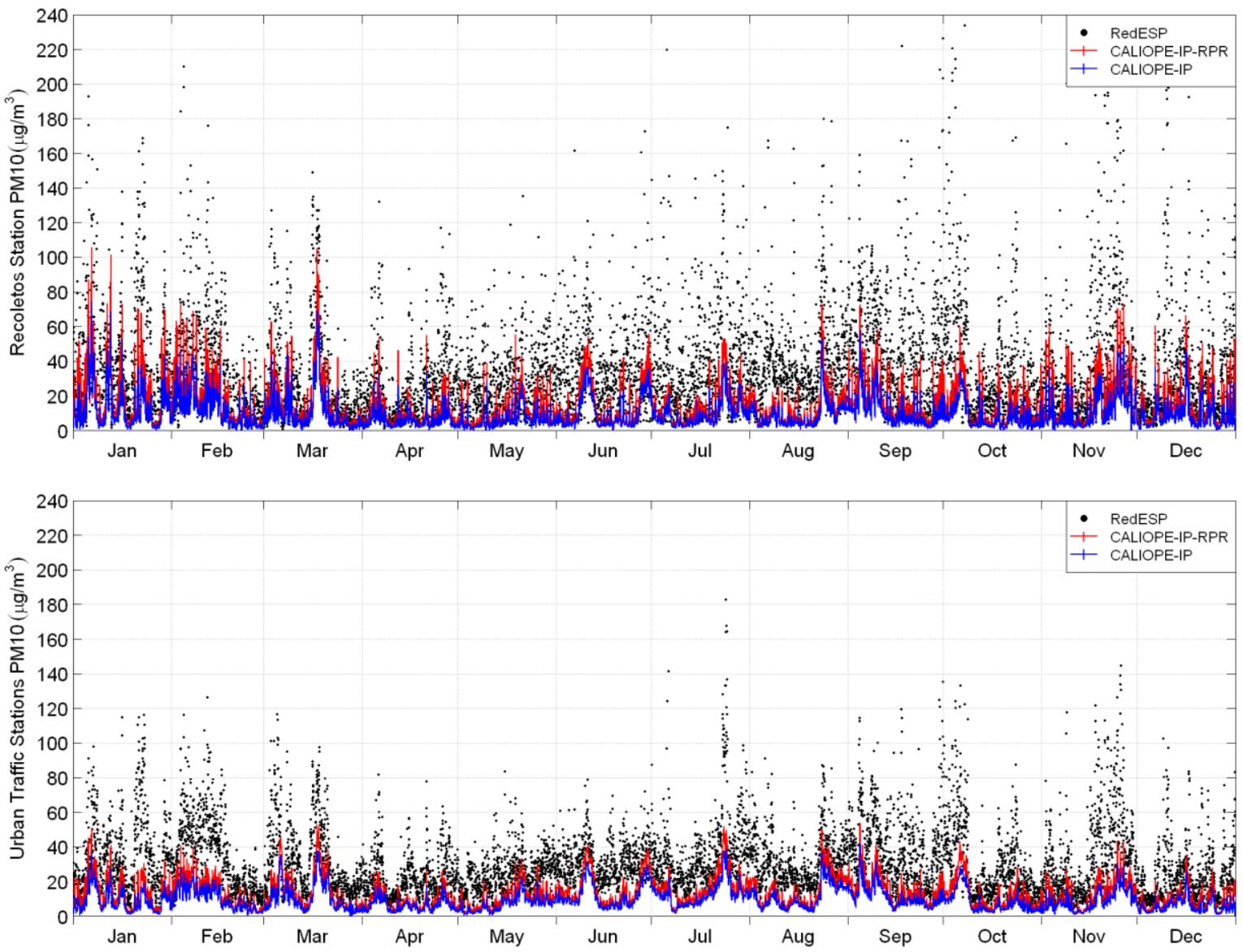